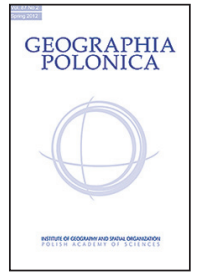

\title{
GEOGRAPHICAL CHARACTERISTICS OF THE TIMBERLINE IN THE CARPATHIANS
}

\author{
Barbara Czajka ${ }^{1}$ - Adam Łajczak ${ }^{2}$ - Ryszard J. Kaczka ${ }^{1}$ \\ ${ }^{1}$ Faculty of Earth Sciences \\ University of Silesia in Katowice \\ Będzińska 60, 41-200 Sosnowiec: Poland \\ e-mails: barczajka@wp.pl・ryszard.kaczka@us.edu.pl \\ ${ }^{2}$ Institute of Geography \\ Pedagogical University of Krakow \\ Podchorażych 2, 30-084 Krakow: Poland \\ e-mail: alajczak@o2.pl
}

\begin{abstract}
The pattern of timberline distribution on mountain ranges world-wide is related to global factors. The basic factor is temperature and the amount of radiation, which falls with increasing distance from the equator. Additionally, this basic relationship is overlaid by the specific features of the type of climate on the massif (degree of continentality or oceanity) and the mass-elevation effect. In the Carpathians, the mass elevation effect seems to have bigger impact on the location of timberline $\left(R^{2}=0.71, p=0.00\right)$ than their latitudinal location $\left(R^{2}=0.56, p=0.00\right)$. The timberline altitude changes by $70 \mathrm{~m}$ a.s.l. $( \pm 20 \mathrm{~m})$ with each degree of latitude. The influence of the type of the climate is complex and it is not clearly visible due to past and recent human impact.
\end{abstract}

\section{Key words}

timberline - global factors $\bullet$ latitude influence $\cdot$ mass-elevation effect $・$ the Carpathians

\section{Introduction}

A timberline ecotone (TE), as an azonal effect of the change in climatic conditions, is a worldwide phenomenon (Grace 1989). The greater the latitude-related shortage of warmth, the lower is the elevation a.s.l. of tree species occurrence. In the Northern
Hemisphere the timberline descends $110 \mathrm{~m}$ with each degree of latitude, disappearing totally at about $70^{\circ} \mathrm{N}$ (Daubenmire 1954; Körner 1998). This dependence is not linear, and moreover, it has a different character in the Northern and Southern Hemisphere (Körner 1998; Cogbill \& White 1991; Jobbágy \& Jackson 2000). 
Numerous studies have reported on the worldwide location of timberlines (Troll 1973a,b; Wardle 1974; Arno 1984; Körner 1998). The timberline in the Alps (Brockmann-Jerosch 1919; Däniker 1923) and the Scandinavian Mountains (Kullman 1991, 2001; Dalen \& Hofgaard 2005; Kullman \& Oberg 2009; Bogaert et al. 2011) have been the most thoroughly examined on a global and European scale. Research on the character of the timberline in the Carpathians has mainly been conducted for individual massifs, with special attention to the TE in the Western Carpathians (Sokołowski 1928; Plesník 1978; Zientarski 1985; Guzik 2008) and Eastern Carpathians (especially Ukrainian) (Jakób 1937; Środoń 1948; Kucharzyk 2006; Kucharzyk \& Augustyn 2008; Kuemmerle et al. 2009; Kucsicsa 2011). Only three studies on this topic covering a larger area of the Carpathians than individual massifs have been made in the last 100 years. The first includes early scientific deliberations on the altitudinal ranges of particular vegetation belts in the former Austro-Hungarian Empire (Fekete \& Blatny 1913-1914). In recent years scientists have become interested in the influence of contemporary climatic change and shifts in land development patterns on the location of the timberline (Shandra et al. 2013; Weisberg et al. 2013). These are not, however, comprehensive studies of the Carpathians: neither study comprises an analysis of the southern slopes of the Southern Carpathians.

Temperature, which decreases with altitude, is the most significant element of the environment determining the appearance of boundaries in high-mountain systems (Tranquillini 1979; Wieser \& Tausz 2007). Nevertheless, it is not the only global factor determining the extent of climatic and vegetation belts. With an increase in the continental character of the climate, a timberline occurs at higher altitudes than in the massifs affected by humid air masses of oceanic climates (Arno 1966, 1984; Holtmeier 1974; Wardle 1986, 1998).

Apart from climatic elements, the geomorphological (geomorphometric) nature of a massif also affects the altitude of the timberline. The mass-elevation effect (mountainmass effect, massenerhebungseffekt, Merriam effect), that is the ratio of a massif's volume to its surface area is of the greatest importance (Kasthofer 1822; Schlagintweit A. \& Schlagintweit H. 1854; Imhof 1900; De Quervain 1904; Zientarski 1985; Guzik 2008). Bigger massifs are more able to absorb radiation and transform it into thermal energy (Tollner 1949). This effect is more visible closer to the centre of the massif and with increase in continental character. The bigger the masselevation effect, the higher the boundaries of vegetation and climatic belts (Fliri 1975; Witmer et al. 1986). It has been indicated that the impact of this effect on the altitude of the TE in Asia is more important than the impact resulting from the latitudinal location of a massif (Fang et al. 2011, 2012).

Besides the size of a massif, the timberline is also affected by the relief of the massif. The more varied it is (the larger the amount of convex and concave landforms), the stronger the erosion and landslides, the more frequent and bigger the avalanches and debris and mud flows etc. which prevent a timberline from reaching its maximum altitude typical of a particular climate (Holtmeier 2009).

One should bear in mind, however, that many global patterns in high-mountain systems have been disturbed by centuries-old human activity (Miehe G. \& Miehe S. 2000; Munteanu et al. 2014). Moreover, what also matters in every individual case is the combination of local conditions constituting the individual character of each massif (including exposure, geology, soil cover, history of glaciations, history of reserve protection) (Holtmeier \& Broll 2005).

The aim of this study is to determine major morphometric features of the timberline in all the Carpathian massifs where it can be found and to identify the global environmental factors, which influence its pattern of distribution. The subject was chosen for study in order to expand knowledge of the interactions between those processes, which affect the highmountain environment of the Carpathians. 


\section{Study sites}

The Carpathians constitute part of the European - African - Asian mountain system, called the Alpine-Himalayan orogenic belt which was formed during the Alpine orogeny by the elevation of sedimentary rocks accumulated in a sea environment (Storetvedt 1990). The Carpathians, which form a $\sim 1300 \mathrm{~km}$ long arc, stretch between 45 and 49 degrees latitude north, and between 17 and 27 degrees longitude east (Fig. 1 and 7). They cover an area of over 190 thousand $\mathrm{km}^{2}$, constituting the second largest (following the Alps) mountain area in Europe (Klimaszewski 1972). Compared to the Alps, the Carpathians are distinguished by much lower solidity and smaller heights (the highest peak of the Carpathians - Gerlach 2655 m a.s.l.; of the Alps - Mont Blanc 4810 m a.s.l.). Geological units in both massifs were formed out of analogous rocks in different ways (Kondracki 1978). The majority of the Carpathians is built of flysch, while a vast range of extinct volcanoes stretches in the central section of the mega-region (Tab.1). Both the abovementioned rock formations are of little importance or do not occur in the Alps whereas a range of calcareous and crystalline rocks, which are developed in the Alps, occur in the form of broken, isolated blocks in the Carpathians (Ksiqzżkiewicz 1965; Kondracki 1978). Only 15 Carpathian massifs were affected by the Pleistocene glaciations, and mountain glaciers do not currently occur in this area.

The climate of the Carpathians has transitional features of continental and oceanic climates and its continental character increases from the west to the east. In winter the Carpathians are usually affected by polar and continental air masses, which come from the east and north-east. For the rest of the year masses of oceanic air reach this area from the north-west, west and south-west (Hess 1965). However, owing to the distance from large sea basins and being screened by the Alps, the Dinaric Mountains and the Czech Massif, the Carpathians are characterised by lower precipitation. The highest annual precipitation rate is observed in the Tatra Mts. $(1800 \mathrm{~mm}$ ) year) (Niedźwiedź et al. 2014), compared to $1500 \mathrm{~mm} /$ year on the peaks of the Southern Carpathians (Furlan 1977). Average annual air temperatures depend on altitude and latitude. In the Tatras (Western Carpathians), the average annual temperature on Kasprowy Wierch Mt. (1991 m a.s.l.) amounts to $-0.8^{\circ} \mathrm{C}$, while in the Bucegi Range (Southern Carpathians), the average annual temperature on Omul Mt. (2507 $\mathrm{m}$ a.s.l.) is $-2.5^{\circ} \mathrm{C}$ (Niedźwiedź 2012).

Several region-based divisions of the Carpathian mega-region have been developed (Hromadka 1956; Mihailescu 1963; Klimaszewski 1972; Mazur \& Luknis 1978; Kondracki 1978; Balon et al. 1995). Due to its systematic character, the physiogeographic regionalisation by Kondracki (1978) tends to be the most favoured by researchers. It is a five-level division, based on the topography, hydrography, and geology. Four provinces can be distinguished: the Western, Eastern, and Southern Carpathians and Apuseni Mts. (Fig.1). Analysing the topography of the Carpathian arc from the north to the south:

- the Babia Góra Massif (1725 m a.s.l.) is the highest massif of the Western Outer Carpathians;

- the Tatra Mts. (Gerlachovský štít 2655 m a.s.I.) and the not much lower Nízke Tatry Mts. (Ďumbier 2043 m a.s.l.) are the highest and the biggest massifs of the Central Western Carpathians;

- the Chornohora Mts. (Outer - Hoverla $2061 \mathrm{~m}$ a.s.l) and the Rodnei Mts. (Inner - Pietrosul 2303 m a.s.l.) are the highest massifs of the Eastern Carpathians;

- the Făgăraș Mts. are the largest massifs in the Southern Carpathians (Moldoveanu 2544 m a.s.l.), in the Bucegi, Retezat and Parâng Mts. the highest peaks exceed 2500 m a.s.l.;

- the Bihorului Mts. are the largest mountain range of the Apuseni Mts. (Curcubăta Mare 1849 m a.s.l.).

A timberline occurs in 54 out of the 124 mountain meso- and microregions distinguished in the Carpathians (Tab.1). In the entire Carpathians the timberline ecotone mainly 
Table 1. Basic information about study areas classified according to Kondracki's regionalisation (1978)

\begin{tabular}{|c|c|c|c|c|c|c|c|c|c|c|c|c|c|c|}
\hline \multirow[b]{2}{*}{ ID } & \multirow{2}{*}{$\begin{array}{l}\overline{\bar{o}} \\
\text { है } \\
\text { 心 }\end{array}$} & \multirow{2}{*}{$\begin{array}{l}\text { 产通 } \\
\text { 总 } \\
0 \text { 过 }\end{array}$} & \multirow[b]{2}{*}{ Mountain range } & \multirow[b]{2}{*}{$\begin{array}{l}\text { Highest peak } \\
\text { [m a.s.I.] }\end{array}$} & \multirow{2}{*}{ 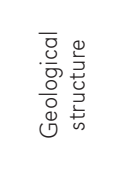 } & \multicolumn{2}{|c|}{ Massif location } & \multirow{2}{*}{ 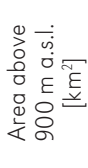 } & \multirow{2}{*}{ 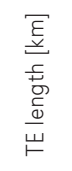 } & \multicolumn{3}{|c|}{ TE altitude [m a.s.I. } & \multirow{2}{*}{ 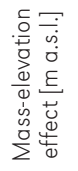 } & \multirow{2}{*}{ 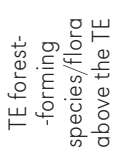 } \\
\hline & & & & & & $\phi$ & $\lambda$ & & & $\sum^{\frac{x}{0}}$ & 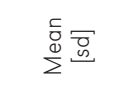 & $\stackrel{5}{\Sigma}$ & & \\
\hline 1 & 513.512 & $\mathrm{PL} / \mathrm{SVK}$ & Babia Góra Mts. & Babia Góra (1725) & $\mathrm{F}$ & 49.57 & 19.53 & 96 & 38 & 1508 & $1370(59)$ & 1106 & 1095 & $\mathrm{NS} / \mathrm{SP}$ \\
\hline 2 & 513.51 & & $\begin{array}{l}\text { Orawsko-żywieckie } \\
\text { Beskidy Mts. }\end{array}$ & Pilsko (1557) & & 49.53 & 19.32 & 98 & 22 & 1496 & $1345(100)$ & 1037 & 1073 & NS/SP \\
\hline 3 & 514.43 & SVK & Mală Fatra Mts. & Vel'ký Kriváń (1709) & $C R, C C$ & 49.16 & 18.96 & 194 & 252 & 1506 & $1212(129)$ & 784 & 1104 & $N S / S P$ \\
\hline 4 & 514.5 & $\mathrm{PL} / \mathrm{SVK}$ & Tatra Mts. ${ }^{\star}$ & Gerlachovský štít (2655) & & 49.20 & 19.96 & 1152 & $1000^{\circ}$ & 1735 & $1428(109)$ & 1024 & 1317 & $\mathrm{NS} / \mathrm{SP}$ \\
\hline 5 & 514.52 & SVK & Vel'ký Choč Mts. & Vel'ký Choč (1611) & CC & 49.15 & 19.34 & 20 & 19 & 1571 & $1330(102)$ & 1033 & 1099 & $\mathrm{NS} / \mathrm{SP}$ \\
\hline 6 & 514.85 & & Vel'ká Fatra Mts. & Ostredok (1592) & $C R, C C$ & 48.94 & 19.11 & 325 & 261 & 1563 & $1229(112)$ & 771 & 1097 & NS/LV \\
\hline 7 & 514.91 & & Nízke Tatry Mts. ${ }^{\star}$ & Ďumbier (2043) & & 48.92 & 19.71 & 1062 & 831 & 1694 & $1410(120)$ & 899 & 1201 & $N S / S P$ \\
\hline 8 & 522.12 & $\mathrm{PL} / \mathrm{SVK} / \mathrm{UKR}$ & Western Bieszczady Mts. & Tarnica (1346) & $\mathrm{F}$ & 49.11 & 22.66 & 192 & 136 & 1290 & $1116(54)$ & 923 & 1021 & $E B / P$ \\
\hline 9 & 522.13 & UKR & $\begin{array}{l}\text { Verkhovynsky Vododilny } \\
\text { khrebet Mts. }\end{array}$ & Pikuj (1408) & & 48.88 & 22.95 & 77 & 64 & 1299 & $1148(55)$ & 855 & 1032 & $E B / P$ \\
\hline 10 & 522.15 & & Gorgany Mts. & Syvulya (1836) & & 48.43 & 24.05 & 2188 & 1003 & 1697 & $1404(116)$ & 809 & 1135 & $\mathrm{NS} / \mathrm{SP}$ \\
\hline 11 & 522.16 & & $\begin{array}{l}\text { Pokuts'ko-Bukovins'kì } \\
\text { Karpati Mts. }\end{array}$ & Rotilo (1483) & & 48.26 & 24.76 & 313 & 56 & 1479 & $1328(60)$ & 1165 & 1085 & NS/LV \\
\hline 12 & 522.21 & & Polonyna Rivna Mts. & Rivna (1482) & & 48.82 & 22.80 & 71 & 70 & 1313 & $1171(63)$ & 960 & 1100 & $E B / P$ \\
\hline 13 & 522.22 & & Polonyna Borzhava Mts. & Stoy (1677) & & 48.62 & 23.25 & 170 & 201 & 1294 & $1105(101)$ & 715 & 1089 & $E B / P$ \\
\hline 14 & 522.23 & & Krasnaja Połonyna Mts. & Syhlansky (1563) & & 48.36 & 23.76 & 172 & 203 & 1457 & $1234(87)$ & 889 & 1115 & $E B / P$ \\
\hline 15 & 522.24 & & Svydivets' Mts. ${ }^{\star}$ & Blyzhnytsa (1883) & & 48.23 & 24.12 & 594 & 550 & 1703 & $1296(123)$ & 760 & 1175 & $N S, E B / L V$ \\
\hline 16 & 522.25 & & Chornohora Mts. ${ }^{\star}$ & Hoverla (2061) & & 48.12 & 24.62 & 642 & 544 & 1847 & $1413(148)$ & 858 & 1230 & $N S / S P, L V$ \\
\hline 17 & 522.26 & & Hrynavsky khrebet Mts. & Baba Lûdowa (1590) & & 47.91 & 24.85 & 914 & 575 & 1611 & $1315(139)$ & 753 & 1135 & NS/LV \\
\hline 18 & 523.1 & UKR/ROU & Maramureşului Mts. ${ }^{\star}$ & Farcău (1957) & $C R, C C, V$ & 47.82 & 24.69 & 1441 & 1722 & 1797 & $1431(127)$ & 812 & 1259 & NS/LV \\
\hline
\end{tabular}




\begin{tabular}{|c|c|c|c|c|c|c|c|c|c|c|c|c|c|c|}
\hline \multirow[b]{2}{*}{ ID } & \multirow{2}{*}{$\begin{array}{l}\overline{0} \\
\text { हे } \\
\text { 今ે }\end{array}$} & \multirow{2}{*}{ 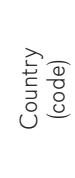 } & \multirow[b]{2}{*}{ Mountain range } & \multirow[b]{2}{*}{$\begin{array}{l}\text { Highest peak } \\
\text { [m a.s.l.] }\end{array}$} & \multirow{2}{*}{ 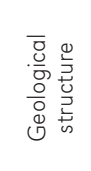 } & \multicolumn{2}{|c|}{ Massif location } & \multirow{2}{*}{ 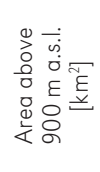 } & \multirow{2}{*}{ 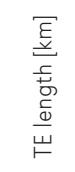 } & \multicolumn{3}{|c|}{ TE altitude [m a.s.I.] } & \multirow{2}{*}{ 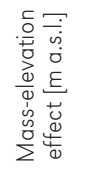 } & \multirow{2}{*}{ 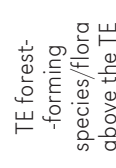 } \\
\hline & & & & & & $\phi$ & $\lambda$ & & & $\sum^{\frac{x}{2}}$ & $\begin{array}{l}\bar{\sigma} \\
\sum^{\infty} \bar{c} \\
\end{array}$ & $\sum$ & & \\
\hline 19 & 523.3 & ROU & Rodnei Mts. * & Pietrosul (2303) & $C R$ & 47.49 & 24.87 & 1249 & 1346 & 1838 & $1433(153)$ & 734 & 1264 & $N S / L V, S P$ \\
\hline 20 & 523.41 & & Obcina Mestecanis Mts. & Lucina (1588) & & 47.63 & 25.11 & 789 & 193 & 1643 & $1370(84)$ & 1093 & 1136 & $N S / L V$ \\
\hline 21 & 523.42 & & Giumalău-Rarău Mts. & Giumalău (1857) & $C R, C C$ & 47.44 & 25,50 & 327 & 97 & 1718 & 1468 (124) & 988 & 1147 & NS/LV \\
\hline 22 & 523.43 & & Pietrosul Mts. & Pietrosul (1794) & $C R$ & 47.29 & 25,55 & 424 & 126 & 1771 & $1487(125)$ & 1017 & 1225 & NS/LV \\
\hline 23 & 523.44 & & Budac Mts. & Budacu (1859) & & 47.08 & 25.69 & 393 & 119 & 1806 & $1527(170)$ & 845 & 1187 & NS/LV \\
\hline 24 & 523.45 & & Ceahlău Mt. & Ocolaşul Mare (1907) & $\mathrm{CC}$ & 46.96 & 25.95 & 128 & 31 & 1864 & $1699(67)$ & 1478 & 1110 & $\mathrm{NS} / \mathrm{SP}$ \\
\hline 25 & 523.46 & & Giurgeu Mts. & Giurgeu (1675) & CR & 46.83 & 25.69 & 371 & 101 & 1674 & $1389(88)$ & 1137 & 1156 & NS/LV \\
\hline 26 & 523.47 & & Hășmaș Mts. & Hășmaşul Mare (1792) & & 46.63 & 25.87 & 830 & 187 & 1784 & $1429(128)$ & 1108 & 1135 & $\mathrm{NS} / \mathrm{LV}$ \\
\hline 27 & 523.56 & & Gutâi Mts. & Gutâiul Mare (1443) & v & 47.70 & 24.83 & 50 & 14 & 1397 & $1311(36)$ & 1211 & 1047 & $\mathrm{NS}, \mathrm{EB} / \mathrm{LV}$ \\
\hline 28 & 523.57 & & Țibleș Mts. & Bran (1840) & $\mathrm{F}$ & 47.51 & 24.25 & 172 & 106 & 1730 & $1335(153)$ & 893 & 1106 & NS/SP, LV \\
\hline 29 & 523.62 & & Călimani Mts.* & Pietrosul (2100) & $\vee$ & 47.12 & 25.09 & 2135 & 673 & 1888 & $1550(141)$ & 1039 & 1190 & $N S / L V, S P$ \\
\hline 30 & & & Gurghiu Mts. & Saca Mare (1776) & & 46.73 & 25.31 & 954 & 36 & 1762 & $1497(100)$ & 1301 & 1145 & $\mathrm{NS} / \mathrm{LV}$ \\
\hline 31 & 523.63 & & Harghita Mts. & $\begin{array}{l}\text { Harghita Mădăraş } \\
(1800)\end{array}$ & & 46.37 & 25.66 & 631 & 82 & 1766 & $1558(118)$ & 1236 & 1147 & $N S / S P$ \\
\hline 32 & 524.2 & & Stânişoarei Mts. & Bivolui (1530) & $\mathrm{F}$ & 47.23 & 25.87 & 408 & 135 & 1531 & $1291(103)$ & 986 & 1070 & $N S / L V$ \\
\hline 33 & 524.3 & & Tarcău Mts. & Grindușu (1664) & & 46.63 & 26.08 & 325 & 32 & 1645 & $1499(92)$ & 1233 & 1176 & $\mathrm{NS} / \mathrm{LV}$ \\
\hline 34 & 524.5 & & Ciucului Mts. & Noscalat (1553) & & 46.33 & 26.22 & 184 & 32 & 1546 & $1351(96)$ & 1156 & 1100 & $\mathrm{NS} / \mathrm{LV}$ \\
\hline 35 & 524.6 & & Oituz (Nemira) Mts. & Nemira Mare (1649) & & 46.19 & 26.36 & 193 & 55 & 1635 & $1423(116)$ & 1108 & 1132 & $N S / L V$ \\
\hline 36 & 525.1 & & Vrancei Mts. & Goru (1785) & & 45.78 & 26.46 & 1823 & 205 & 1772 & $1487(115)$ & 1026 & 1150 & $E B, N S / L V$ \\
\hline 37 & 525.2 & & Buzăului Mts. & Ciucaș (1956) & & 45.40 & 25.97 & 880 & 499 & 1831 & 1392 (111) & 1043 & 1151 & EB, NS/LV \\
\hline 38 & 525.3 & & Gârbova Mts. & Neamtu (1923) & & 45.43 & 25.66 & 441 & 407 & 1888 & 1446 (132) & 830 & 1251 & $E B, N S / L V$ \\
\hline
\end{tabular}




\begin{tabular}{|c|c|c|c|c|c|c|c|c|c|c|c|c|c|c|}
\hline \multirow[b]{2}{*}{ ID } & \multirow{2}{*}{$\begin{array}{l}\overline{\bar{o}} \\
\stackrel{\circ}{\xi} \\
\text { ڤે }\end{array}$} & \multirow{2}{*}{ 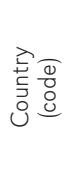 } & \multirow[b]{2}{*}{ Mountain range } & \multirow{2}{*}{$\begin{array}{l}\text { Highest peak } \\
\text { [m a.s.I.] }\end{array}$} & \multirow{2}{*}{ 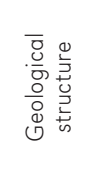 } & \multicolumn{2}{|c|}{ Massif location } & \multirow{2}{*}{ 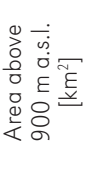 } & \multirow{2}{*}{ 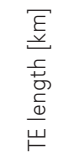 } & \multicolumn{3}{|c|}{ TE altitude [m a.s.I.] } & \multirow{2}{*}{ 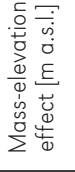 } & \multirow{2}{*}{ 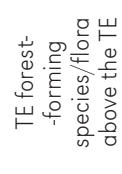 } \\
\hline & & & & & & $\phi$ & $\lambda$ & & & $\sum^{x}$ & 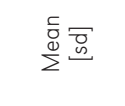 & $\frac{c}{\Sigma}$ & & \\
\hline 39 & 531.11 & ROU & Bucegi Mts. ${ }^{\star}$ & Omu (2505) & $\mathrm{CC}, \mathrm{F}$ & 45.39 & 25.42 & 589 & 361 & 1957 & $1643(130)$ & 1139 & 1343 & NS/LV \\
\hline 40 & 531.12 & & Leaota Mt. & Leaota (2133) & $C R$ & 45.30 & 25.29 & 253 & 224 & 1941 & $1561(154)$ & 891 & 1269 & NS/LV \\
\hline 41 & 531.13 & & Piatra Craiului Mt. & Pietra Craiului (2238) & $\mathrm{CC}$ & 45.51 & 25.22 & 181 & 95 & 1973 & $1657(128)$ & 1326 & 1224 & $N S / L V, S P$ \\
\hline 42 & 531.14 & & lezerul Mt. & lezeru (2463) & $C R$ & 45.47 & 24.99 & 545 & 574 & 2003 & $1656(115)$ & 1182 & 1378 & NS/SP, LV \\
\hline 43 & 531.15 & & Făgăraș Mts. * & Moldoveanu (2544) & & 45.56 & 24.69 & 1690 & 2358 & 1999 & $1590(161)$ & 976 & 1440 & $N S, E B / S P$ \\
\hline 44 & 531.17 & & Cozia Mt. & Cozia (1668) & & 45.32 & 24.34 & 37 & 9 & 1656 & $1503(86)$ & 1284 & 1158 & NS/LV \\
\hline 45 & 531.21 & & Căpățânii Mt.* & Nedeia (2130) & & 45.30 & 23.95 & 482 & 580 & 1865 & $1631(122)$ & 1063 & 1349 & NS/LV \\
\hline 46 & 531.22 & & Parâng Mts. ${ }^{\star}$ & Parângul Mare (2519) & $C R, C C$ & 45.35 & 23.64 & 739 & 855 & 2015 & $1628(150)$ & 1089 & 1459 & $N S / S P, L V$ \\
\hline 47 & 531.24 & & Lotrului Mts. & Șteflești, (2242) & CR & 45.54 & 23.95 & 765 & 626 & 1964 & $1677(149)$ & 853 & 1437 & $N S / L V, S P$ \\
\hline 48 & 531.25 & & Cindrel Mts. * & Cindrel (2245) & & 45.60 & 23.78 & 687 & 168 & 1941 & $1751(85)$ & 1422 & 1330 & NS/SP, LV \\
\hline 49 & 531.26 & & Sebes (Șureanu) Mts. & Pătru (2130) & & 45.54 & 23.49 & 1119 & 474 & 1928 & $1651(103)$ & 1239 & 1285 & NS/SP \\
\hline 50 & 531.32 & & Retezat Mts. ${ }^{\star}$ & Peleaga (2509) & & 45.38 & 23.00 & 522 & 587 & 2058 & $1615(182)$ & 1067 & 1462 & $N S / S P$ \\
\hline 51 & 531.33 & & Godeanu-Cernei Mts. ${ }^{\star}$ & Gugu (2291) & $\mathrm{CR}, \mathrm{CC}$ & 45.16 & 22.69 & 546 & 690 & 2027 & $1495(62)$ & 1015 & 1433 & $\begin{array}{l}\text { NS, EB/ } \\
\text { LV, SP }\end{array}$ \\
\hline 52 & 531.34 & & Țarcu Mts. ${ }^{\star}$ & Căleanu (2192) & $C R$ & 45.36 & 22.58 & 628 & 493 & 1980 & $1534(196)$ & 705 & 1346 & $\begin{array}{l}\text { NS, EB/ } \\
\text { LV, SP }\end{array}$ \\
\hline 53 & 531.36 & & Vâlcan Mts. & Vâlcan (1946) & $C R, C C$ & 45.26 & 23.09 & 600 & 352 & 1705 & $1449(82)$ & 1091 & 1191 & $N S, E B / L V$ \\
\hline 54 & 542.1 & & Bihorului Mts.* & Curcubăta Mare (1849) & $\mathrm{V}, \mathrm{CC}$ & 46.55 & 22.99 & 2336 & 560 & 1798 & $1524(127)$ & 880 & 1205 & NS/LV \\
\hline
\end{tabular}

CR - crystalline rocks; CC - carbonate rocks; F - flysch; V - volcanic rocks; NS- Norway spruce; EB - European beech; SP - Swiss pine; LV - low vegetation (glades, clearings, herbs, grasses); P - Polonynas.

a- Guzik (2008).

* massifs of post-glacial relief. 


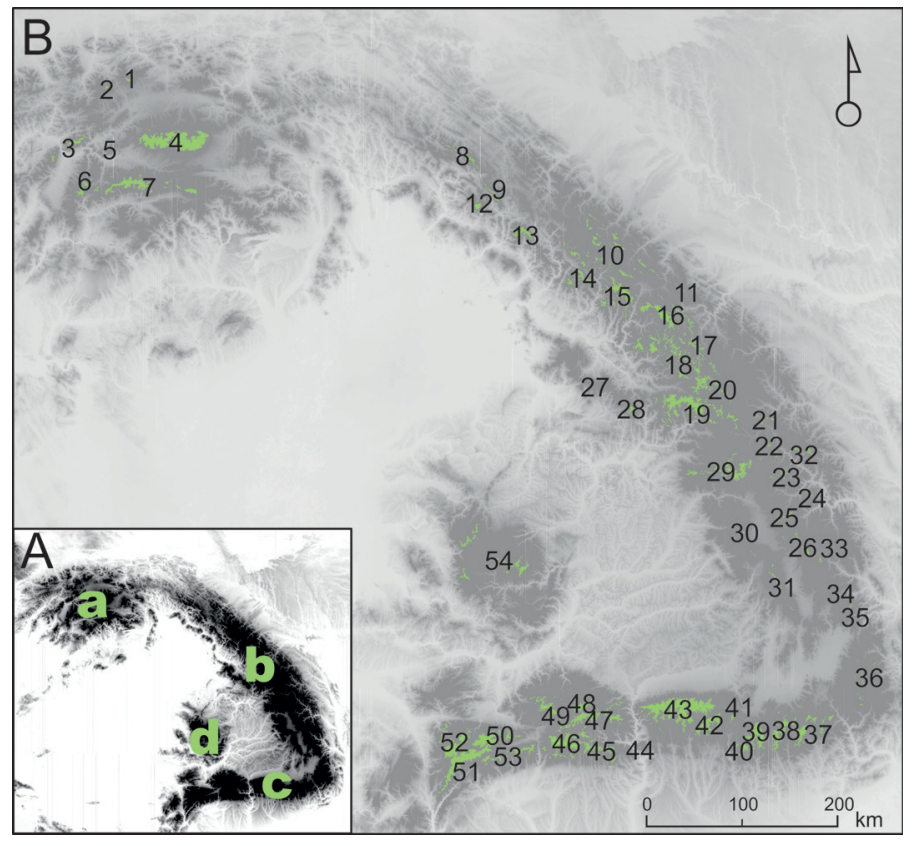

Figure 1. Carpathian provinces (A): a - Western Carpathians; b - Eastern Carpathians; $c$ - Southern Carpathians; $d$ - Apuseni Mts. Massifs where a timberline was formed (B). Numbers 1-54 correspond to the 'ID' column in Table 1

consists of Norway spruce (Picea abies), with a small amount of Swiss pine (Pinus cembra) and European larch (Larix decidua). Beech (Fagus sylvatica) is the main forest species forming the timberline in some massifs. Shrub vegetation, mostly dwarf mountain pines (Pinus mugo) with some juniper (Juniperus L.), alder (Alnus viridis), willows (eg. Salix silesiaca) and Rhododendron kotschyi, forms a natural plant community above it (Sokołowski 1928; Piękoś-Mirkowa \& Mirek 1996). As a result of centuries-old anthropogenic activity the content, structure and height range of vegetation and climatic belts have been considerably disturbed (Munteanu et al. 2014).

\section{Methodology}

The research covered an area of $34,000 \mathrm{~km}^{2}$, which includes the Carpathian massifs. The study involved any mountains with a clearly formed timberline, defined as the zone (ecotone) separating the area of dense forest (spruce or beech) from the zone with single trees, dwarf mountain pine or tall-herb and grassy communities (Troll 1973a; Grace 1989).

Image interpretation and GIS analyses were performed with Open Source, QuantumGIS 2.0.1. software (with the use of the OpenLayers Plugin) and ArcMap 10.2.2. by ESRI (with the use of Spatial Analyst, 3D Analyst and Topography Tools extensions). Satellite imaging and Digital Elevation Models were applied in the study.

The contemporary course of the timberline was marked out through image interpretation of satellite images carried out in the 21st century (2002-2012). High-resolution (0.5-0.6 m) GeoEye-1 images in RGB composition, available from the World Imagery service on ESRI licence, were applied. At this resolution $88 \%$ of the course of the timberline was determined. For the remaining $12 \%$ for which this resolution images were not available, image interpretation was performed with an accuracy of $30 \mathrm{~m}$ (LANDSAT-7 ETM+). 
The image interpretation allowed one to generate a linear vector layer depicting the alignment of the timberline in the Carpathians, which was subsequently converted into a raster layer with a pixel of $30 \times 30 \mathrm{~m}$ (compatible with the accuracy of the Digital Elevation Model applied).

Global coverage elevation model drawn up in 1998-2008 were employed in spatial analyses. The ASTR (Advanced Spaceborne Thermal Emission Reflection Radiometer) GDEM-2 model was used. This was made available in 2011 and is distinguished by greater accuracy than the earlier, global elevation imaging for the Carpathians (SRTM3 and GDEM-1). A pixel covers 1 arc-second $(30 \mathrm{~m})$, and the model itself is the Digital Surface Model. Horizontal resolution is 2.4 arc-seconds $(72 \mathrm{~m})$ and elevation error is $-0.7 \mathrm{~m}$ (Tachikawa et al. 2011).

A physicogeographical description was drawn up for each of the 54 mountain ranges analysed including the following features:

a) name of the meso - or macroregion where a timberline was formed and the symbol in the decimal classification according to Kondracki (1978). The only exception is the considering of the Tatra Mts. (Western and Eastern) as a whole in order to facilitate the comparison of the results with the outcome of earlier research (e.g. Guzik 2008);

b) latitude and longitude of the mountain group centroid;

c) country in which it is located (Poland, Slovakia, Ukraine or Romania);

d) the highest elevation with altitude;

e) area of the mountain range above 900 m a.s.l.;

f) general geological structure of the mountain in the timberline area (crystalline core, carbonate rocks, flysch or volcanic rocks);

g) forest forming species making up the upper wooded section (in the Carpathians it is Norway spruce - Picea abies L. Karst or beech - Fagus sylvatica L.);

h) vegetation communities above the timberline in general terms (dwarf mountain pine or tall-herb and grassy communities); i) mass-elevation effect, that is the height a massif would have if it was transformed into a plateau, preserving its base area and volume (De Quervain 1904). The height of $900 \mathrm{~m}$ a.s.l., that is, the height at which bordering rivers which drain massifs are most often located, was selected as the base area.

Also the contemporary course of the timberline and the area above it were described calculating the:

a) length of the timberline, in particular mountain ranges;

b) mean, maximum and minimum altitudes of the timberline;

c) area above the timberline;

d) mass-elevation effect above the timberline;

e) Topographic Position Index of the area above the timberline which allowed the provision of a characteristic giving quantitative values describing the diversity of relief (Jennes 2006);

f) timberline development index (K): a modified index originating from hydrology (shoreline development index) (Pociask-Karteczka \& Baścik 2006), which allows the provision of quantitative characteristics describing the extent of variation of the TE.

$$
K=\frac{L}{2 \sqrt{\pi A}}
$$

$K$ - shoreline development

[timberline development]

$L$ - lake shoreline length in $\mathrm{km}$

[timberline length in $\mathrm{km}$ ]

$A$ - lake area in $\mathrm{km}^{2}$

[2D area above the timberline in $\mathrm{km}^{2}$ ]

\section{Results}

In the Carpathians the timberline ecotone occurs in mountains between $49.6^{\circ} \mathrm{N}$ latitude in the north (Babia Góra Mt.) and $45.2^{\circ} \mathrm{N}$ in the south (Godeanu-Cernei Mts.), and between $19.0^{\circ} \mathrm{E}$ longitude in the west (Mală Fatra Mts.) and $26.5^{\circ} \mathrm{E}$ in the east (Vrancei Mts.) (Tab. 1). The timberline occurs in 54 macro- and mesoregions: 7 in the Western Carpathians, 31 in the Eastern Carpathians, 
15 in the Southern Carpathians and the Biharu Massif in the Apuseni Mts. The total length of the timberline amounts to nearly $21,000 \mathrm{~km}$. Its length varies depending on the massif: from several (Vel'ký Choč Mts., Gutâi Mts. and Cozia Mt.) to over 2000 kilometres (Făgăraş Mts.). According to the division into Carpathian provinces, the greatest part of the ecotone studied is located in the Eastern $(9600 \mathrm{~km})$ and Southern $(8500 \mathrm{~km})$ Carpathians, compared to the Western $(2400 \mathrm{~km})$ and Apuseni Mts. $(560 \mathrm{~km})$.

The timberline in the Carpathians runs at a mean altitude of $1750 \mathrm{~m}$ a.s.l. Its highest mean alignment can be observed in the Cindrel Mts. and on Ceahlău Mt. Its maximum altitude of occurrence is much higher, reaching up to 2050 m a.s.l. in the Retezat Mts. In this Carpathian province (Southern Carpathians) the altitude at which the timberline occurs is the least varied ( $S D=80 \mathrm{~m}$ ) and, additionally, it reaches the highest mean elevation there (1600 $\mathrm{m}$ a.s.l.), which distinguished this province. The lowest mean location of the timberline in mesoregions is observed in the Western Carpathians (1330 m a.s.l, SD = 80) while in Mală and Vel'ká Fatra Mts. it does not even reach the mean elevation of $1250 \mathrm{~m}$ a.s.l. In the Eastern Carpathians the timberline runs on average a little higher (1380 m a.s.I.), but is the most varied in this respect $(S D=140)$. Polonynski Hory and Lesiste Beskids (Western Bieszczady, Verkhovynsky Vododilny khrebet, Polonyna Rivna and Borzhava Mts.) are located where the mean altitude of the timberline is the lowest in the Carpathians ( $1100 \mathrm{~m}$ a.s.l.). The timberline in the Carpathians is locally lowered (as a result of natural processes and human activity) even as low as $700 \mathrm{~m}$ a.s.I. (e.g. Mală Fatra, Polonyna Borzhava, Rodnei and Tarcău Mts.).

The latitude of a particular massif is one of the factors affecting the character of the TE (Fig. 2). The further to the south, the higher the average and maximum elevation of the timberline. This trend is considerable and the factor accounts for variance exceeding 56\%. The observed interdependence reached the highest value $\left(R^{2}=0.56, p=0.00\right)$ for the regression equation describing the dependence of the maximum and mean forest range a.s.l. on the latitude of the centroid of each massif. Even the minimum forest range depended on a massif's latitudinal location $\left(R^{2}=0.13, p=0.007\right)$. The mean altitude of the timberline in the northernmost massifs $\left(49^{\circ} \mathrm{N}\right)$ is $1300 \mathrm{~m}$ a.s.l. In the massifs located further to the south $(48,47$, 46 and $45^{\circ} \mathrm{N}$ ) the timberline is on average located at an elevation of 1280, 1410, 1490 and $1580 \mathrm{~m}$ a.s.l. respectively. The TE in the massifs located at the $48^{\circ}$ parallel (mostly the Polonynski Hory and Lesiste Beskids ranges) is located the lowest and the general pattern is not preserved. If these mountains are excluded the average elevation of the TE at $48^{\circ} \mathrm{N}$ is located at the mean altitude of $1350 \mathrm{~m}$ a.s.l. With each degree of latitude the timberline altitude increases by $70 \mathrm{~m}$ a.s.I. $(S D=18)$.

The location of the massif on the east west axis should theoretically correspond to changes in the continental character of the local climate. Authors haved examined this relationship. The analyses carried out for the northern part of the Carpathians (from the Mală Fatra to the Verkhovynsky Vododilny khrebet Mts. - 10 massifs) and the Carpathian range in the south (from Tarcău to Vrancei Mts. - 18 massifs). The results did not reveal such a dependence (linear regression parameters: $\left.R^{2}<0.08, p>0.01\right)$. Only a slight relationship between maximum timberline altitude on northern massifs and longitude was noticed ( $\left.R^{2}=0.61 ; p=0.007\right)$.

The relationship between the timberline location and the mass-elevation effect (that is the size of a range) (Fig. 3) is significant, explaining $71 \%$ of the variance of maximum forest ranges $(p=0.00)$. It is also an important factor regarding the mean altitude of the $T E\left(R^{2}=0.53, p=0.00\right)$. Also in this case the minimum of the range of altitudes of the forest margin does not depend on the size of a mountain range $\left(R^{2}=0.01, p=0.85\right)$. In some massifs the TE occurs at lower altitudes, in contrast to the average trend. This concerns ranges such as the Polonynski Hory Mts. (Polonyna Krasnaja, Rivna and Borzhava Mts.) and the Tatra and Svydivets' Mts. However, the TE 
is located much higher than the average in the Ceahlău Massif, in the Piatra Craiului and the Cindrel Mts.

In the Carpathians the area of a mountain range has a significant influence on its timberline length. Analysing the relation of these two elements one may observe differences in behaviour between massifs with an area of up to $1700 \mathrm{~km}^{2}$ and those exceeding this area (Fig. 4A). The former (black circles on the chart) constitute the majority (93\%) and are distinguished by a direct dependence of the TE length on the size of the massif $\left(R^{2}=0.68, p=0.00\right)$. In this group the larger the massif, the longer the timberline in the TE ecotone, which can reach a length of up

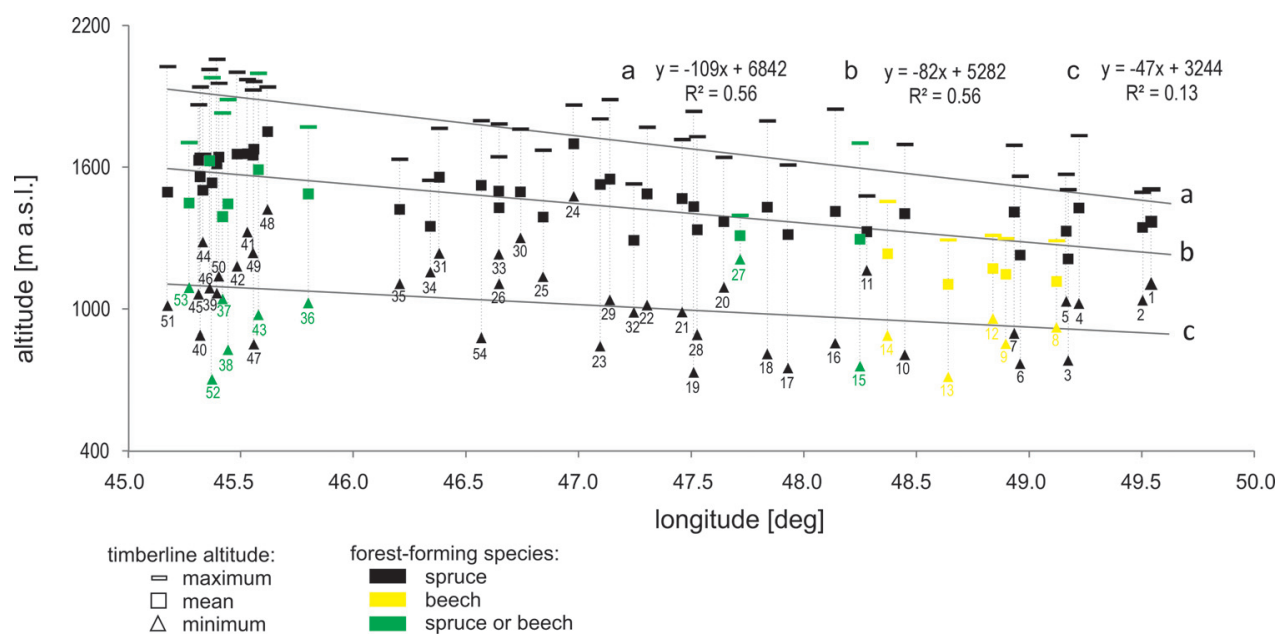

Figure 2. The altitude of timberline compared with the latitude of a mountain range. The numbers correspond to particular mountain ranges from the ID column in Table 1

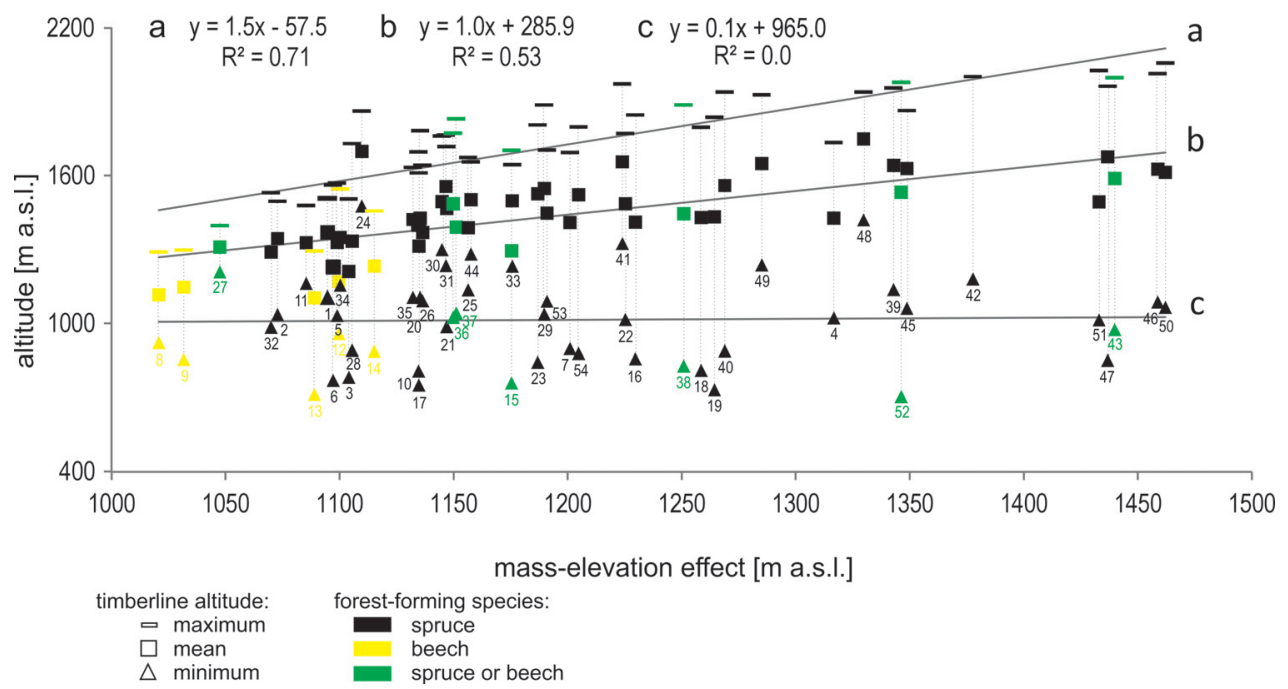

Figure 3. The altitude of timberline compared with the mass-elevation effect. The numbers correspond to particular mountain ranges from the ID column in Table 1 

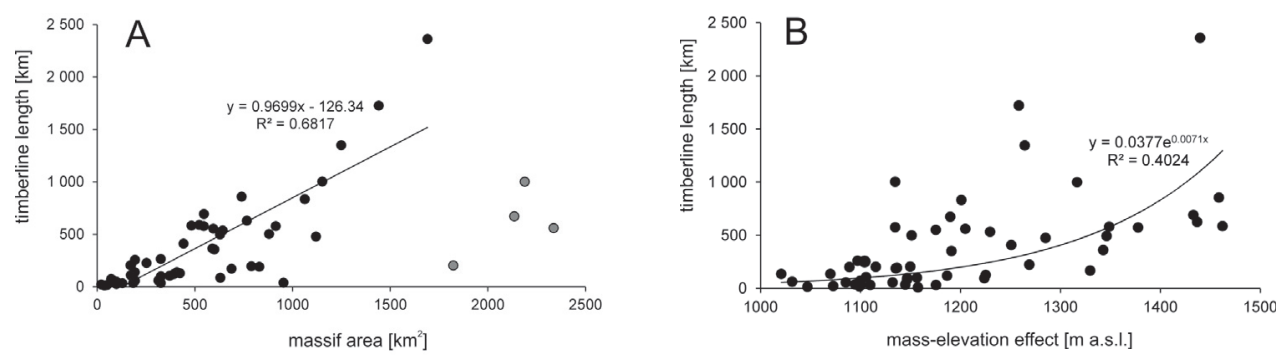

Figure 4. The dependence of the timberline length on the massif area (A) and its mass-elevation effect (B). Population grouped on two: black and grey circles (explenations in the text)

to 2400 km (Făgăraș Mts.). For the mountains with an area larger than $1700 \mathrm{~km}^{2}$, including Gorgany, Călimani, Vrancei and the Bihorului Mts., the interdependence analysed is of a different nature. The relation between the timberline length and the mass-elevation effect is not linear and is less significant $\left(R^{2}=0.40\right)$ (Fig. 4B).

The development of the line representing the TE in the Carpathian massifs is highly varied and ranges from $3 \mathrm{~km} / \mathrm{km}^{2}$ in the Gutâi Mountains, to $31 \mathrm{~km} / \mathrm{km}^{2}$ in the Făgăraş Mountains and $33 \mathrm{~km} / \mathrm{km}^{2}$ in the Maramureșului Mts. The results were compared with the relief variation indexes for the area above the TE. The relief variation was presented with the TPI variance value for each of the massifs. Two groups may be distinguished among the massifs examined (Fig. 5). Statistically significant linear dependence $\left(R^{2}=0.30, p=0.00\right)$ is observed in the majority of the mountains (93\%): the more varied the relief above the timberline, the more varied the course of the TE. However, the interrelationship disappears above a critical value (TPI>170 variance). The Piatra Craiului and lezerul Mts. (small but soaring massifs), as well as the Tatra and the Făgăraș Mountains (vast and high mountain ranges), belong to the group of massifs with the highest TPI variance.

Coniferous species, mainly spruce with to a lesser extent Swiss pine, constitute a dominant element of the uppermost forests in the Carpathians. However, beech also appears at the timberline in $26 \%$ of the Western and Eastern Carpathian massifs (Tab. 1). The altitudes of the spruce and mixed timberline are similar regarding both maximum and mean elevation, and SD between the massifs (Fig. 6). The beech timberline runs much lower $(\sim 300 \mathrm{~m})$ than the upper wooded section of spruce forest. The beech timberline occurs in the Western Bieszczady, Verkhovynsky Vododilny khrebet and on the Polonyna

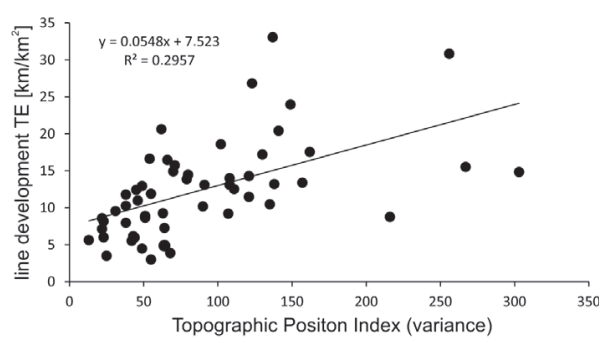

Figure 5. The TE line development depending on relief variation, expressed with the Topographic Position Index

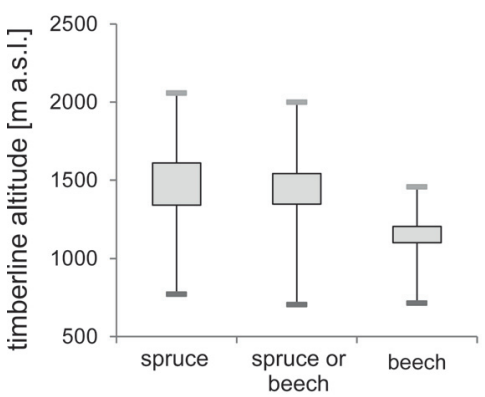

Figure 6. Altitude of the timberline (maximum, mean, standard deviation from the mean and minimum) depending on the forest-forming species 
Krasnaja, Rivna and Borzhava Mts. Considering the mass-elevation effect of these ranges and their latitude, the timberline should run at about 100-150 m a.s.l. higher (Fig. 2 and 3). Also in the case of the partly spruce and partly beech timberline (Svydivets', Vrancei, Buzăului, Gârbova, Tarcău, Vâlcan, Godenau-Cernei, Făgăraș and Gutâi Mountains) a much lower course of the timberline may be observed in relation to the surrounding massifs, but it only involves its mean altitude ranges (Fig. 2).

\section{Discussion and conclusions}

The precision of the analyses and the accuracy of the results obtained depend on the quality of cartographic materials used. For the majority of the area studied (for $88 \%$ of the timberline length) high-definition GeoEye-1 satellite images (accuracy below $1 \mathrm{~m}$ ) were the main source used for photo-interpretation. They allow one to mark out the course of the empirical timberline with exceptional accuracy for such studies (YongMing et al. 2010). Image interpretation of the remaining part of the ecotone $(12 \%)$, which is based on satellite images with $30 \times 30 \mathrm{~m}$ resolution, is distinguished by lower precision, however it was also successfully employed in research on the functioning of geosystems in the Carpathians (Kucharzyk 2006; Griffiths et al. 2014; Tanese 2013). The inaccuracy of the ASTR digital terrain models with 1 arc - the second definition - may have the greatest effect on the unreliability of the study. Nevertheless, the data constitute the most accurate and widely available global study on altitude (Tachikawa et al. 2011).

In accordance with the classic understanding of a timberline (Troll 1973a), temperature is the most important element determining the occurrence of biotic boundaries in the environment. In mountain systems it is important on a local (microclimate connected with the variety of relief), regional (e.g. the diversity of temperature depending on the exposure of slopes) and sub-regional scale (Jobbágy \& Jackson 2000). This study, which involves the entire Carpathian arc owing to its spatial range (latitudinal range $=5^{\circ}$ ), falls into to the last category. In these categories of global relationships, phenomena in with the temperature and the amount of radiation decline with an increase in distance from the equator (Körner 1998; Cogbill \& White 1991; Jobbágy \& Jackson 2000), play an important role. Owing to the fact that as closer to the equator, that the satisfactory tree growth conditions appear at higher and higher altitudes. According to these rule the TE in the Southern Carpathians occurs much higher (maximum range of the TE up to the elevation of $2058 \mathrm{~m}$ a.s.I.) than in other Carpathian provinces (maximum range of the TE up to an elevation of $1888 \mathrm{~m}$ a.s.l.). In North American massifs the average altitude of the timberline increases by $110 \mathrm{~m}$ with every degree of latitude (Daubenmire 1954). However, in the entire Northern Hemisphere, between $45^{\circ} \mathrm{N}$ and $70^{\circ} \mathrm{N}$, the location of the timberline changes by $75 \mathrm{~m}$ per degree (Hermes 1955; Körner 1998). In the Carpathians this general assumption is not so clear. The TE of the massifs situated at a latitude of $48^{\circ} \mathrm{N}$ is located lower than in the massifs located at $49^{\circ} \mathrm{N}$ (on average by $20 \mathrm{~m}$ a.s.l.). If one excludes those massifs where above timberline 'poloninas' occurred from the study (Verkhovynsky Vododilny khrebet, Polonyna Krasnaja, Rivna and Borzhava Mts.), the assumption becomes valid and the TE altitude changes by $70 \mathrm{~m}$ a.s.l. $( \pm 20 \mathrm{~m})$ with each degree of latitude. These results are compatible with studies in the Northern Hemisphere and those conducted in particular mountain ranges. The timberline in the Ural Mountains rises by $71 \mathrm{~m}$ per every degree of latitude, in Central Siberia by $89 \mathrm{~m}$, while in Eastern Siberia by $76 \mathrm{~m}$ (Malyshev 1993). Nevertheless, the timberline variance in the Carpathians is only partly explained by north-south location ( $\max$ $\mathrm{R}^{2}=0.53$ ).

Comparing the course of the timberline in the Carpathians with the course of the $10^{\circ} \mathrm{C}$ isotherm of the warmest month (Daubenmire 1954; Holtmeier 1974), it was observed that only $11 \%$ of the timberline length was located near (up to $200 \mathrm{~m}$ ) the climatic range of tree species marked out in such a manner (Shandra 
et al. 2013). Apart from the global influence of temperature changeability, other factors (e.g. anthropogenic impact) play a significant role in the Carpathians. In high-mountain European areas it mostly manifests itself in sheep and cattle grazing, clearing of dwarf mountain pine, and possible ore metallurgy and mining (Gellrich et al. 2007; Sitko \& Troll 2008) whereas the timberline in Fenoscandia is affected by breeding of reindeer (Bogaert et al. 2011). The traditional forms of land use throughout the last 50 years are disappearing (Tasser et al. 2007; Guzik 2008). It has been observed in the Alps that transformation in the landscape structure is heavily determined by the systems of anthropogenic disturbance (Kulakowski et al. 2011; Garbarino et al. 2013). Nowadays, the minimum forest ranges registered in the Carpathians (Tab. 1) are not related to the global factors examined (apart the latitudinal location). A considerable lowering of the timberline in the Carpathians largely results from human economic activity. In the last 260 years there have been numerous changes in the forest cover of the Carpathian region. The spatial distribution of these changes mainly depends on the administrative - political and economic situation of the inhabitants of a particular region in a specific period (Munteanu et al. 2014). In the last 50 years the forest cover in the Western Carpathians has been increasing steadily (Guzik 2008; Ostafin 2009). In the Romanian Carpathians the situation is different, since at least 1990 a decrease in forest acreage has been observed which is caused by illegal forest management, including in the protected areas (Mihai et al. 2007; Irland \& Kremenetska 2009; Kuemmerle et al. 2009; Knorn et al. 2012) or by forest clearing for tourism infrastructures (Huzui et al. 2012). However, on the regional scale the timberline has been increasing in altitude since 1880 , which is tightly connected with the introduction of protective measures (Gerard et al. 2006; Olah \& Boltiziar 2009) and the abandonment of fields and meadows (Mihai et al. 2007; Zausková et al. 2011). The change of the timberline location caused by contemporary climatic changes is another important phenomenon (Shandra et al. 2013). Nevertheless, the reaction of mountain forests to climatic changes is masked by rapidly changing land use practices.

The mass-elevation effect has a significant impact on the location of the timberline. Several dozen years ago the mass-elevation effect of the Carpathian ranges could only be described with regard to quality, e.g. through establishing a hierarchy of mountain ranges (Zientarski 1985). The importance of the masselevation effect was noticed very early, it was described by De Quervain (1904) in the Alps as early as at the beginning of 20th century. The quantitative specification of the masselevation effect for mountain ranges requires (in addition to calculating its area) calculating its volume which can be obtained in a fast and reliable way owing to modern digital data. In the Carpathians the mass-elevation effect of particular mountain ranges varies considerably (mean $1241 \mathrm{~m}$ a.s.l.; $S D=118$ ). This effect, together with the potential radiation account, explains $80 \%$ of the variance of the mountains in New Zealand (Case \& Duncan 2014). It has been proved that the mass-elevation effect has an extensive influence on the location of the snowline in Tibet (Fang et al. 2011) and on the timberline of Central Asian massifs (Fang et al. 2012) where it is the second most significant factor explaining the variance of timberline altitude (Fang et al. 2012). In 2014 a metaanalysis of the timberline was carried out on locations in the Northern Hemisphere. The analysis of over 500 timberlines proved that the mass-elevation effect was the most important element accounting for the variance (49\%), while together with the latitude and continentality factors it explained 90\% of the variance (Zhao et al. 2014). Similarly, the mass-elevation effect in the Carpathian mountain ranges has a bigger impact on the location of the timberline than their latitudinal location $\left(R^{2}=0.79\right)$.

It should be emphasized that it is complicated to separate the influence of latitude from the impact of the mass-elevation effect on timberline altitude in the area examined. The largest mountain ranges in the Carpathians 
(mass-elevation effect $\geq 1400$ m a.s.l.) - the Făgăraș, Parâng, Retezat, Lotrului and Godenau-Cernei Ranges, are located southernmost in the entire Carpathians $\left(45^{\circ} \mathrm{N}\right)$.

Apart from latitude, the longitude of a massif, which in Europe and Asia is connected with the transfer from an oceanic into a continental climate, is also important. The differences between humidity (precipitation amount and regime) and thermal parameters (the differences in annual temperature amplitudes) affect changes in species distribution and their altitudinal ranges (Caccianiga et al. 2008). The occurrence or lack of spring drought is of particular importance (Pache et al. 1996). A timberline appears even 200-1000 m higher inland than in coastal areas (Leuschner 1996). In the Alps the structure and position of the timberline differs considerably between the oceanic pre-alpine belt and the continental inner Alps (Ozenda 1985; Theurillat \& Guisan 2001; Caccianiga et al. 2008). In the more continental alpine climate beech disappears, giving way to Swiss pine, while the forest is located at much higher elevations (Ozenda 1985). The factor discussed is not, however, the major one as it only plays a supportive role (Caccianiga et al. 2008). It is also confirmed by the results of analyses in the Carpathians. Due to the specific shape of the Carpathian arc and a significant dispersion of the massifs, the pattern of air mass movement is complex, while the influence of longitude on the climate is not linear (Kondracki 1978) in contrast to the Alps, where their dense structure and virtually linear alignment from the south-west to the north-east produce stable and clear pluvial and thermal conditions (Barry 1994). Cold and humid air masses, which come from the Atlantic and the Arctic, affect the north-western Alpine slopes. On the other hand, warm and dry air masses from Africa have an impact on the southern-eastern slopes.

In the majority of massifs of the Western and Eastern Carpathians (to the north of the Vrancei Mountains) Norway spruce is a natural forest forming species of the timberline. In the remaining, southernmost massifs it locally gives way to beech (Tab. 1).
In the Polonynski Hory and Lesiste Beskids, that are much further to the north, beech trees are similarly a characteristic element of the Carpathian timberline. There is not yet unanimous consensus on the reason for such a state of affairs and it remains unknown whether it is natural or anthropogenic (Środon 1948; Golubec 1978; Kucharzyk 2006; Rob \& Taut 2007). After the later climate cooling (begins 5000 years ago) the range of beech gradually lowered and rowan and green alder trees began to spread in the mountain pastures (Kucharzyk 1999). Skroppa (2003) argues that the beech timberline in the Polonynski Hory and Lesiste Beskids is a natural infilling between its northern and southern genetic populations (the so-called spruce dysjunction). If the beech timberline results from anthropogenic activity, it is still an open question why spruce forests regenerate so slowly (Kolisuk 1958; Dolecki 1984). The isolated spruce trees that occurred above the beech timberline and analysis of their growth record and condition did not confirm that they had reached their ecological limit (Dolecki 1984; Komendar \& Fiodor 1987; Kaczmarczyk 2011). It should be observed, however, that the beech timberline appears about 200$300 \mathrm{~m}$ lower than that of the spruce in the massifs surrounding the Polonynski Hory and Lesiste Beskids, both compared to ranges similar in terms of latitude (Gorgany, Nízke Tatry Mts.) and in terms of mass-elevation effect (Babia Góra, Pilsko, and Ceahlău Mts. or Vel'ký Choč Mts.).

The location of a timberline is also affected by a variety of other biotic and abiotic components (Czajka et al. 2015a,b). Nevertheless, none of them is able to transform a timberline in a supra-regional sense.

The Carpathian timberline functions in different physicogeographical conditions from those in the Alps, the largest mountain macro-region in Europe. One of the key differences is the area occupied by the ecotone (Troll 1973a; Pecher et al. 2011). Part of the Carpathian massifs (Western Carpathians and part of Eastern Carpathians) is even located $1.5^{\circ}$ further to the north (Fig. 7), 
which results in lower annual temperatures whereas part of the Alpine massifs reaches further to the south $\left(44^{\circ} \mathrm{N}\right)$ (Maritime Alps) and remains under the influence of the Mediterranean climate. The TE in the Carpathians is characterised by clearly separated, small (in terms of mass-elevation effect) mountain ranges which results in a considerable fragmentation of the timberline ecotone and the predominance of the influence of local conditions over global relationships on its formation (Fig. 7).

\section{Acknowledgments}

The work described here forms part of research project NN 306049139 of the Polish National Science Centre, entitled Role of spatial and temporal dynamics of tree growth in dendrochronological climate reconstructions of Carpathians.

\section{Editors' note:}

Unless otherwise stated, the sources of tables and figures are the authors' on the basis of their own research.

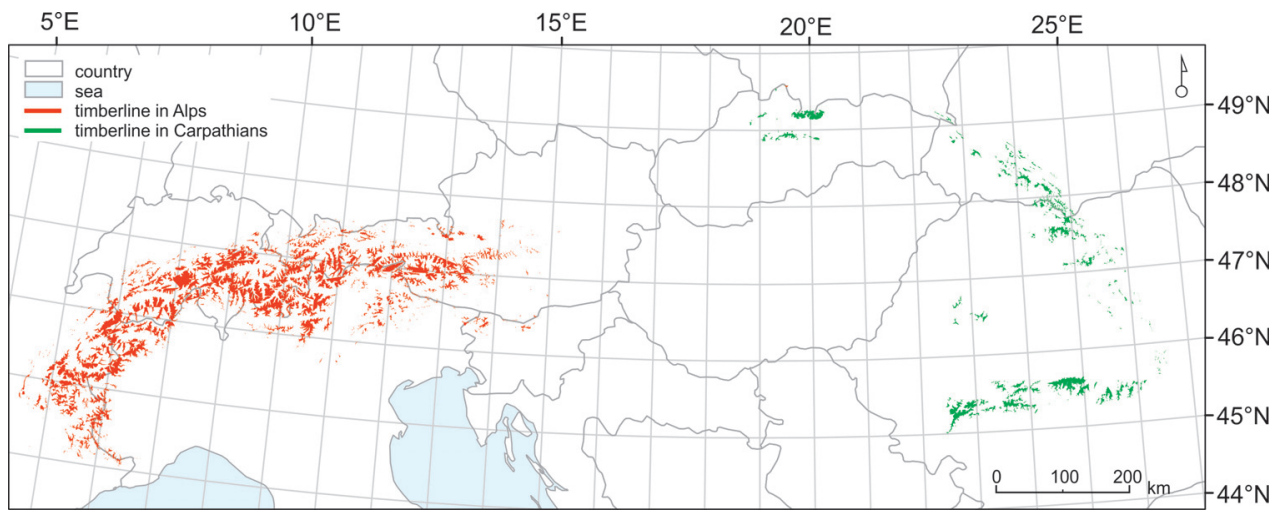

Figure 7. Spatial comparison of the Alpine and Carpathian timberline characteristics. The alignment of the timberline in the Alps on the basis of Pecher et al. (2011)

\section{References}

ARNO S.F., 1966. Interpreting the timberline: An aid to help park naturalists to acquaint with the subalpine-alpine ecotone of Western North America. Missoula, MT: University of Montana [MA thesis].

Arno S., 1984. Timberline: Mountain and Arctic Forest Frontiers. Seattle: The Mountaineers.

Balon J., German K., Kozak J., Malara H., WidacKI W., ZIAJA W., 1995. Regiony fizycznogeoraficzne [in:] J. Warszyńska (ed.), Karpaty Polskie: Przyroda, człowiek i jego działalność, Kraków: Uniwersytet Jagielloński, pp. 117-130.
BARRY R.G., 1994. Past and potential future changes in mountain environments: A review [in:] M. Beniston (ed.), Mountain environments in changing climates. London-New York: Routledge Publishing Company, pp. 3-33.

Bogaert R.V., Haneca K., Hoogesteger J., Jonasson Ch., Dapper De M., Callaghan V., 2011. A century of tree line changes in sub-Arctic Sweden shows local and regional variability and only a minor influence of 20th century climate warming. Journal of Biogeography, vol. 38, no. 5, pp. 907-921.

Brockmann-Jerosch H., 1919. Baumgrenze und Klimacharakter. Beiträge zur geobotanischen Landesaufnahme, 6, Zürich: Rascher. 
Caccianiga M., Andreis C., Armiraglio S., LeOnelli G., Pelfini M., Sala D., 2008. Climate continentality and treeline species distribution in the Alps. Plant Biosystems, vol. 142, no. 1, pp. 66-78.

CASE B.S., DUNCAN R.P., 2014. A novel framework for disentangling the scale-dependent influences of abiotic factors on alpine treeline position. Ecography, vol. 37, no. 9, pp. 838-851.

Cogbill C.V., White P.S., 1991. The latitude-elevation relationship for spruce-fir forest and treeline along the Appalachian mountain chain. Vegetatio, vol. 94, no. 2, pp. 153-175.

CZAJKA B., KACZKA R.J., ŁaJCZAK A., 2015a. The $d y$ namics of the timberline ecotone on the asymmetric ridge of the Babia Góra Massif, Western Carpathians. Geographia Polonica, vol. 88, no. 2, pp. 85-102.

CZAJKA B., KacZKA R.J., ŁaJCZAK A., 2015b. Timberline in the Carpathians: An overview. Geographia Polonica, vol. 88, no. 2, pp. 7-34.

Dalen L., HofgaArd A., 2005. Differential regional tree line dynamics in the Scandes Mountains. Arctic, Antarctic and Alpine Research, vol. 37, no. 3, pp. 284-296.

DÄNIKER A., 1923. Biologische Studien uber Baumund Waldgrenze, insbesondere uber die klimatischen Ursachen und deren Zusammenhange. Vierteljahrsschrift der Naturforschenden Gesellschaft in Zürich, 68, Zürich: Naturforschende Gesellschaft.

Daubenmire R., 1954. Alpine timberlines in the Americas and their interpretation. Butler University Botanical Studies, vol. 11, art. 14, pp. 119-136.

De Quervain A., 1904. Die Hebung der atmosphärischen Isothermen in den Schweizer Alpen und ihre Beziehung zu den Höhengrenzen. Gerlands Beiträge zur Geophysik, 6, pp. 481-533.

DOLECKI L., 1984. Karły świerkowe na połoninach Bieszczadów Zachodnich. Chrońmy Przyrodę Ojczysta, 3, pp.13-20.

Fang H., Baiping Z., Yonghui Y., Yunhal Z., Yu P., 2011. Mass elevation effect and its contribution to the altitude of snowline in the Tibetan Plateau and surrounding areas. Arctic, Antarctic, and Alpine Research, vol. 43, no. 2, pp. 207-212.

Fang H., Yonghui Y., Shibao D., Chun W., RaNHAO S., JUAN X., BaIPING Z., 2012. Mass elevation effect and its forcing on timberline altitude.
Journal of Geographical Sciences, vol. 22, no. 4, pp. 609-616.

Fekete L., Blattny T., 1913-1914. Die Verbreitung der forstlich wichtigsten Bäume und Sträucher im Ungarischen Staate. 1 Bd., Selmecbanya.

FLIRI F., 1975. Das Klima der Alpen im Raum von Tirol: Monographien zur Landeskunde Tirols. Folge 1 Innsbruck-Munich: Universtitätsverlag Wagner,

FuRLAN D., 1977. The climate of Southeast Europe [in:] C.C. Wallen (ed.), Climates of central and southern Europe. Amsterdam-Oxford-New York: Elsevier, pp. 185-235.

Garbarino M., Lingua E., Weisberg P.J., Bottero A., Meloni F., Motta R., 2013. Land-use history and topographic gradients as driving factors of subalpine Larix decidua forests. Landscape ecology, vol. 28, no. 5, pp. 805-817.

Gellrich M., Baur P., Koch B., Zimmermann N.E., 2007. Agricultural land abandonment and natural forest re-growth in the Swiss mountains: A spatially explicit economic analysis. Agricultural Ecosystems Environments, vol. 118, no. 1-4, pp. 93-108.

Gerard F., Bugár G., Gregor M., Halada L., Hazeu G., Huiti H., Köhler R., Kolár J., luque S., Malcher C., Olschofsky K., Petit S., Pino J., Smith G., Thomson A., Wachowicz M., Bezák P., Boltiziar M., DeBadts E., Halabuk A., Manchester S., Mojses M., Petrovic F., Roda F., Roscher M., Tuominen S., Ziese H., 2006. Linking pan-European land cover change to pressures on biodiversity - Biopress final report 1st January 2003 - 31st December 2005, sections 5 and 6. NERC/Centre for Ecology \& Hydrology, http://nora.nerc.ac.uk/500891/1/060228finalr eport.pdf [5 March 2015].

GolubeC M. A., 1978. El'niki Ukrainskih Karpat. Kiev: Naukova Dumka.

Grace J., 1989. Tree lines. Philosophical Transactions of the Royal Society, Series B, 324, pp. 233-245.

Griffiths P., Kuemmerle T., Baumann M., Radeloff V.C., AbRUdAn I.V., LIESKovsky J., Munteanu C., Ostapowicz K., Hostert P., 2014. Forest disturbances, forest recovery, and changes in forest types across the Carpathian ecoregion from 1985 to 2010 based on Landsat image composites. Remote Sensing of Environment, 151, pp. 72-88. 
Guzık M., 2008. Analiza wpływu czynników naturalnych i antropogenicznych na kształtowanie się zasięgu lasu i kosodrzewiny w Tatrach. Kraków: Uniwersytet Rolniczy im. Hugona Kołłątaja. Wydział Leśny. Katedra Botaniki Leśnej i Ochrony Przyrody [PhD thesis].

HeRmes K., 1955. Die Lage der oberen Waldgrenze in den Gebirgen der Erde und ihr Abstand zur Schneegrenze (Kolner geographische Arbeiten ). Köln: Selbstverlag des Geographischen Instituts der Universität.

Hess M., 1965. Piętra klimatyczne w polskich Karpatach Zachodnich. Zeszyty Naukowe UJ. Prace Geograficzne, 11, Kraków: Uniwersytet Jagielloński.

Holtmeler F.K., 1974. Geooekologische Beobachtungen und Studien an der subarktischen und alpinen Waldgrenze in vergleichender Sicht. Wiesbaden: Franz Steiner.

Holtmeler F-H., Broll G., 2005. Sensitivity and response of northern hemisphere altitudinal and polar treelines to environmental change at landscape and local scales. Global Ecology and Biogeography, vol. 14, no. 5, pp. 395-410

Holtmeler F.H., 2009. Mountain timberlines: Ecology, patchiness, and dynamics. Advances in Global Change Research, 36, Dordrecht: Springer.

HROMADKA J., 1956. Nové orografické třídění ČSR. Sborník Československé společnosti zeměpisné, 61, 161-180.

Huzui A.E., Calin I., Patru-Stupariu I., 2012. Spatial pattern analyses of landscape using multitemporal data sources [in:] I. Pătru-Stupariu, M. Pătroescu, C.I. lojă, L. Rozylowicz (eds.), Procedia Environmental Sciences: 2011 International Conference of Environment-Landscape-European Identity: Volume 14, pp. 98-110.

IMHOF E., 1900. Die Waldgrenze in der Schweiz. Gerland's Beitrage zur Geophysik, vol. 4, no. 3, Leipzig: Engelmann, pp. 241-330.

Irland L.C., KRemenetska E., 2009. Practical economics of forest ecosystem management: The case of the Ukrainian Carpathians [in:] S.W.S. Keeton (ed.), Ecological economics and sustainable forest management: Developing a transdisciplinary approach for the Carpathian Mountains, Lvov: Ukrainian National Forestry University Press, pp. 180-200.
JAKÓB M.L., 1937. Uwagi nad górna granica lasu w Gorganach Centralnych. Sylwan, 2-3, pp. 89-101.

JENNES J., 2006. opographic Position Index (tpi_jen. avx) extension for ArcView 3. x, v. 1.3 a. Jenness Enterprises, http://www.jennessent.com/ arcview/tpi.htm [5 March 2015].

JobBÁGY E.G., JACKSON R.B., 2000. Global controls of forest line elevation in the Northern and Southern Hemispheres. Global Ecology and Biogeography, vol. 9, no. 3, pp. 253-268.

KaCZMARCZYK M., 2011. Analiza występowania i kondycji świerka pospolitego w Bieszczadach Wysokich. Sosnowiec: Wydział Nauk o Ziemi. Uniwersytet Śląski [MA thesis].

KASTHOFER K., 1822. Bemerkungen auf einer Alpenreise über den Susten, Gotthard, Bernhardin, und über die Oberalp, Furka und Grimsel. Aarau.

Klımaszewski M. (ed.), 1972. Geomorfologia Polski. Warszawa: Państwowe Wydawnictwo Naukowe.

Knorn J., Kuemmerle T., Radeloff V.C., Szabo A., Mindrescu M., Keeton W.S., Abrudan I.V., Griffiths P., Gancz V., Hostert P., 2012. Forest restitution and protected area effectiveness in post-socialist Romania. Biological Conservation, vol. 146, no. 1, pp. 204-212.

Kolisuk V.G., 1958. Suèasna verhnâ mera lisu v Ukraïns'kih. Kiev: AN URSR.

KOMENDAR V.I., FIODOR S.S., 1987. Study of the restoration of the upper forest limit in the Carpathians Ukrainian SSR USSR. Tiscia, 22, pp. 55-60.

KondraCKi J., 1978. Karpaty. Warszawa: Wydawnictwa Szkolne i Pedagogiczne.

KÖRNER Ch., 1998. A re-assessment of high elevation treeline positions and their explanation. Oecologia, vol. 115, no. 4, pp. 445-459.

KsıAżKIEWICZ M., 1965. Zarys geologii Polski. Warszawa: Wydawnictwo Geologiczne.

KUCHARZYK S., 1999. Wpływ mrozów w zimie 1928/ 1929 na rozwój drzewostanów w Bieszczadach i w Bieszczadzkim Parku Narodowym. Sylwan, vol. 143, no. 8, pp. 25-47.

KUCHARZYK S., 2006. Ekologiczne znaczenie drzewostanów w strefie górnej granicy lasu w Karpatach Wschodnich i ich wrażliwość na zmiany antropogeniczne. Roczniki Bieszczadzkie, 14, pp. 15-43.

KucharzYK S., Augustrn M., 2008. Dynamika górnej granicy lasu w Bieszczadach Zachodnich 
- zmiany w ciagu póttora wieku. Studia Naturae, vol. 54, no. 2, pp. 133-156.

KUCSICSA G., 2011. Considerations on the timberline in the Rodna Mountains National Park. Revue Roumaine de Géographie/ Romanian Journal of Geography, vol. 55, no. 1, pp. 57-61.

Kuemmerle T., Chaskovskyy O., Knorn J., Radeloff V.C., Kruhlov I., Keeton W., Hostert P., 2009. Forest cover change and illegal logging in the Ukrainian Carpathians in the transition period from 1988 to 2007. Remote Sensing of Environment, vol. 113, no. 6, pp. 1194-1207.

KULAKOWSKI D., BeBI P., Rixen C., 2011. The interacting effects of land use change, climate change and suppression of natural disturbances on landscape forest structure in the Swiss Alps. Oikos, vol. 120, no. 2, pp. 216-225.

KulLman L., 1991. Cataclysmic response to recent cooling of a natural boreal pine (Pinus sylvestris L.) forest in northern Sweden. New Phytologist, vol. 117, no. 2, pp. 351-360.

KULLMAN L., 2001. 20th century warming and treelimit rise in the southern Scandes of Sweden. Ambio, vol. 30, no. 2, pp. 72-80.

Kullman L., Oberg L., 2009. Post-Little Ice Age tree line rise and climate warming in the Swedish Scandes: A landscape ecological perspective. Journal of Ecology, vol. 97, no. 3, pp. 415-429.

LEUSCHNER C., 1996. Timberline and alpine vegetation on the tropical and warm-temperate oceanic islands of the world: Elevation, structure and floristics. Vegetation, vol. 123, no. 2, pp. 193-206.

Malyshev L., 1993. Levels of the upper forest boundary in Northern Asia. Vegetatio, vol. 109, no. 2, pp. 175-186.

MAZUR E., LUKNIS M., 1978. Regionálne geomorfologické členenie SSR. Geografický Časopis, vol. 30, no. 2, pp. 101-125.

Miehe G., Miehe S., 2000. Comparative high mountain research on the treeline ecotone under human impact. Carl Troll's "Asymmetrical Zonation of the Humid Vegetation Types of the World" of 1948 Reconsidered. Erdkunde, vol. 54, no. 1, pp. 34-50.

Minallescu V., 1963. Carpatii Sud-Estici de teritoriul, R.P. Romine. Studiu de geografie fizica $\mathrm{cu}$ privire speciala la relief. Cluj: Editura stiintifica.
Mihal B., Savulescu I., Sandric I., 2007. Change detection analysis (1986-2002) of vegetation cover in Romania. A study of alpine, subalpine, and forest landscapes in the lezer Mountains, Southern Carpathians. Mountain Research and Development, vol. 2, no. 3, pp. 250-258.

Munteanu C., Kuemmerle T., Boltiziar M., Butsic V., Gimmi U., Halada L., Kaim D., Király G., Konkoly-Gyuró E., KozAK J., LIESKOVSKY J., Mojses M., Müller D.,Ostafin K., Ostapowicz K., Shandra O., Stych P., Walker S., Radeloff V.C., 2014. Forest and agricultural land change in the Carpathian region - A meta-analysis of long-term patterns and drivers of change. Land Use Policy, 38, pp. 685-697.

NiedźWiedźT., 2012. Climate [in:] D. Lóczy, M. Stankoviansky, A. Kotarba (eds.), Recent Landform Evolution. The Carpatho-Balkan-Dinaric Region, Dordrecht: Springer, pp. 19-30.

Niedźwiedź T., Łupikasza E., Pińskwar I., KundzeWicz Z.W., Stoffel M., MaŁarzeWski Ł., 2014. Variability of high rainfalls and related synoptic situations causing heavy floods at the northern foothills of the Tatra Mountains. Theoretical and Applied Climatology, vol. 119, no. 1-2, pp. 273-284.

Olah B., Boltiziar M., 2009. Land use changes within the Slovak biosphere reserves' zones. Ekológia, vol. 28, no. 2, pp.127-142.

Ostafin K., 2009. Zmiany granicy rolno-leśnej w środkowej części Beskidu Średniego od połowy XIX wieku do 2005 roku. Kraków: Wydawnictwo Uniwersytetu Jagiellońskiego.

Ozenda P., 1985. La végétation de la chaıne Alpine dans l'espace montagnard Européen. Paris: Masson.

Pache G., Michalet R., Aime S., 1996. A seasonal application of the Gams (1932) method, modified Michalet (1991): The example of the distribution of some important forest species in the Alps. Dissertationes Botanicae, 258, pp. 31-54.

Pecher C., Tasser e. Tappeiner U., 2011. Definition of the potential treeline in the European Alps and its benefit for sustainability monitoring. Ecological Indicators vol. 11, no. 2, pp. 438-447.

PięKós-Mirkowa H., Mirek Z., 1996. Zbiorowiska roślinne [in:] Z. Mirek (ed.), Przyroda Tatrzańskiego Parku Narodowego, Kraków-Zakopane: Tatrzański Park Narodowy, pp. 237-274. 
PLESNík P., 1978. Man's influence on the timberline in the West Carpathian Mountains, Czechoslovakia. Arctic, Antarctic and Alpine Research, vol. 10, no. 2, pp. 495-504.

Pociask-KarteczKa Z., Baścik M. (eds.), 2006. Zlewnia - właściwości i procesy. Kraków: Wydawnictwo Uniwersytetu Jagiellońskiego.

RoB M., TăUT I., 2007. Considerations concerning the altitudinal limit of the beech forests from the Gutâi mountains. Bulletin of University of Agricultural Sciences and Veterinary Medicine Cluj-Napoca. Horticulture, vol. 64, no. 1-2, pp. 261-265.

SChlagintweit, A., Schlagintweit H., 1854. Neue Untersuchungen über die physikalische Geographie und die Geologie der Alpen. Leipzig.

Shandra O., Weisberg P., Martazinova V., 2013. Influences of climate and land use history on forest and timberline dynamics in the Carpathian Mountains during the twentieth century [in:] J. Kozak, K. Ostapowicz, A. Bytnerowicz, B. Wyżga (eds.), The Carpathians: Integrating nature and society towards sustainability, environmental science and engineering. Berlin-Heidelberg: Springer Verlag, pp. 209-223.

Sitko I., Troll M., 2008. Timberline changes in relation to summer farming in the Western Chornohora (Ukrainian Carpathians). Mountain Research and Development, vol. 28, no. 3-4, pp. 263-271.

SKROPPA T., 2003. EUFORGEN technical guidelines for genetic conservations and use for Norway spruce (Picea abies). Rome: International Plant Genetics Resources Institute.

SoKOŁOWSKI M., 1928. O górnej granicy lasu w Tatrach. Kraków: Zakłady Kórnickie.

Storetvedt K.M., 1990. The Tethys Sea and the Alpine-Himalayan orogenic belt: Mega-elements in a new global tectonic system. Physics of the Earth and Planetary Interiors, vol. 62, no. 1-2, pp. 141-184.

Środoń A., 1948. Górna granica lasu na Czarnohorze i w Górach Czywczyńskich. Rozprawy Wydziału Matematyczno-Przyrodniczego Polskiej Akademii Umiejętności, vol. 72, no. 7, pp. 513-606.

TachiKaWa T., Hato M., KaKu M., IWASAKI A., 2011, The characteristics of ASTER GDEM version 2. Geoscience and Remote Sensing Symposium (IGARSS), IEEE International, pp. 3657-3660.
TANASE G., 2013. Evoluția limitei superioare a pădurii în masivul Giumalău în perioada 1855 2006. Revista GEOCONCEPT, 1.

Tasser E., Walde J., Tappeiner U., Teutsch A., NogGLER W., 2007. Land-use changes and natural reforestation in the Eastern Central Alps. Agriculture, Ecosystems and Environment, vol. 118, no. 1-4, pp. 115-129.

Theurillat J.P., Guisan A., 2001. Potential impact of climate change on vegetation in the European Alps: A review. Climatic Change, vol. 50, no. 1-2, pp. 77-109.

TOLLner H., 1949. Der Einfluß großer Massenerhebung auf die Lufttemperatur und die Ursachen der Hebung der Vegetationsgrenzen in den inneren Ostalpen. Archiv für Meteorologie, Geophysik und Bioklimatologie. Serie B1, vol. 1, no. 3-4, pp. 347-372.

TRANQUILLINI W., 1979. Physiological ecology of the alpine timberline - tree existence at high altitudes with special reference to the European Alps. Ecological Studies, 31, Berlin: Springer.

TROLL C., 1973a. The upper timberlines in different climatic zones. Arctic, Antarctic and Alpine Reserche, vol. 5, no. 3, pp. 3-18.

Troll C., 1973b. High mountain belts between the polar caps and the equator: Their definition and lower limit. Arctic, Antarctic and Alpine Research, vol. 5, no. 3, pp. A19-A27.

WARdLE P., 1974. Alpine timberlines [in:] J.D. Ives, R.G. Barry (eds.), Arctic and alpine environment, London: Methuen, pp. 371-401.

Wardle P., 1986. Alpine vegetation of New Zealand: A review [in:] B. Barlow (ed.), Flora and fauna of Australasia: Ages and origins, Melbourne: CSIRO, Australian Systematic Botany Society, pp. 45-61.

WARDLE P., 1998. Comparison of alpine timberlines in New Zealand and the Southern Andes. Journal of the Royal Society of New Zealand, Miscellaneous Series, 48, pp. 69-90.

Weisberg P.J., Shandra O., Becker M.E., 2013. Landscape influences on recent timberline shifts in the Carpathian Mountains: Abiotic influences modulate effects of land-use change. Arctic, Antarctic and Alpine Research, vol. 45, no. 3, pp. 404-414. 
Wieser G., TAusz M. (eds.), 2007. Trees at their upper limit: Treelife limitation at the alpine timberline. Dordrecht: Springer.

Witmer U., Filliger P., Kunz S., Küng P., 1986. Erfassung, Bearbeitung und Kartieren von Schneedaten in der Schweiz. Geographica Bernensia G25, Bern: Geographisches Institut der Universität Bern.

YongMing T., Hong W., XingGuo Z., XiaOLI G., 2010. Using GeoEye remote sensing image to make 1:5000 remote sensing image of south mountainous area IN JiNan. Urban Geotechnical Investigation \& Surveying, vol. 4: 038.
Zausková L., Fejes J., Kysucká K., 2011. Zmeny a pustnutie pol'nohospodárskej krajiny $v k$. ú. Podhorie. Banská Bystrica: Univerzita Mateja Bela.

ZhaO F., Zhang B., Pang Y., YaO Y., 2014. A study of the contribution of mass elevation effect to the altitudinal distribution of timberline in the Northern Hemisphere. Journal of Geographical Sciences, vol. 24, no. 2, pp. 226-236.

ZienTARSKI J., 1985. Wpływ wzniesienia oraz wielkości masywu górskiego na kształtowanie się górnej granicy lasu w Polsce. Poznań: Akademia Rolnicza [PhD thesis]. 